\title{
Problems and Suggestions on Piano Course Teaching in Pre-school Education Major in Colleges and Universities
}

\author{
He Zhang \\ Xi'an Fanyi University \\ Xi'an, China
}

\begin{abstract}
At present, the country is in a high regard for pre-school education. The introduction of many policies made our country extremely lack of early childhood teachers, so more and more colleges also have pre-school education programs. Piano is a professional skill that pre-school teachers must master, through the study on the teaching mode of preschool education professional piano course, pointed out that there are problems in the teaching of pre-school education professional piano courses. It also puts forward improvement suggestions from four aspects: teaching environment, teaching form, teaching content and teaching assessment, efforts to improve the teaching effect of pre-school education piano courses.
\end{abstract}

\section{Keywords—pre-school education; piano teaching; advice}

\section{INTRODUCTION}

At present, the country is in a high regard for pre-school education, especially after the two-child policy was fully opened, the government strives to expand public kindergartens and strongly encourages the construction of private kindergartens, mass new kindergartens have sprung up all over the country, child teachers are extremely deficient. With the development of education in China, higher vocational or even secondary school graduates can no longer meet the needs of society for high-quality professionals, colleges and universities have become the main force to train preschool teachers, a growing number of colleges and universities have opened the pre-school education professional, moreover, the curriculum setting and teaching methods of education in pre-school are attracting more and more attention, the teaching effects of various courses have been significantly improved in continuous teaching reform. Art is an important part of the five fields of preschool, it can improve the sensitivity of children to "beauty", develop children's aesthetic and learn to express, promote the perfection of children's personality. Children have a natural love for music, music is indispensable in children's art activities, and preschool teachers must have a certain level of music literacy. And playing piano and singing are indispensable in pre-school music activities, so the ability of piano playing is an important professional skill that preschool teachers must master, so for pre-school education students, the opening of the piano course is a must. Through the development of preschool education in colleges and universities in recent years, preschool education piano curriculum teaching mode and teaching methods and methods are also constantly improving, but after the student's response after learning and after we communicated with the kindergarten, we found that piano is the most difficult skill course for preschool education, there are still many problems in the current curriculum teaching, this will directly or indirectly affect the improvement of students' piano skills. So how to improve students' musical literacy, how to improve the teaching effect of piano course, how to develop higher level preschool teacher talents for the society are questions that we have to think about as frontline teachers.

\section{THE PROBLEMS OF PRE-SCHOOL EDUCATION PROFESSIONAL PIANO COURSES}

\section{A. Students Aspects of the Problem}

1) Students' music foundation and music quality are weak: The pre-school education students in our country have unified enrollment through the college entrance examination, different from the arts college entrance examination the students, they did not have an extra unified examination of piano subjects during the college entrance examination, therefore, most students did not learn piano performance before entering colleges and universities[1]. Even some students have insufficient knowledge of preschool education, do not know that pre-school education major needs to learn piano lessons. This directly led to the prevalence of preschool education students in colleges and universities generally low musical quality, weak basis. In addition, the school curriculum time setting and the actual work of kindergarten for piano level requirements, the teaching task of piano course in colleges and universities has become very heavy.

2) Problems encountered during the learning process: The piano course is a practical course, there are fundamental differences in the way of learning in theory course. Most students in preschool education did not come into contact with piano before entering university, in their hearts, 
Learning is sitting in the classroom with books in your arms, they did not have the habit of going to the piano room, students need a quick adaptation process for learning piano lessons.

The piano is one of the most difficult courses in all technical courses of pre-school education. It takes a lot of time to practice after class, however, there are many courses to be learned in pre-school education, for example, students in the theory course need to learn: preschool education, preschool hygiene, pre-school psychology and teaching activity design in various fields. In the skills class, In addition to the piano, students also need to study art, dance, vocal music, manual and other courses. Each course requires a certain amount of spare time, This can easily lead to students not having enough spare time to practice, unable to finish the homework assigned by the teacher in class, It is easy to create frustration and fear in the learning process, it directly affects the teaching effect of piano lessons.

\section{B. Problems in Teaching}

1) Teaching environment: Nowadays, the professional piano lessons of education in colleges and universities are mainly taught by digital piano, cncentrate dozens of digital pianos in one classroom, ensure that each student has a digital piano, and equipped with projector, speaker, camera first class, it can be taught by computer and corresponding software.

The advantage of digital piano collective teaching is to reduce education cost effectively, through the operation of the central console, the teacher can perform the demonstration, and the collective teaches the difficult knowledge, conduct collective practice instruction, the problem of shortage of teachers is solved. Students can use earphones when playing in class, so it doesn't interfere with each other when play the piano. The downside of the digital piano collective is, schools to save teachers and input costs, It is easy to cause too many people to attend class, influence teaching effect, even if very modern teaching and teaching forms, there should be science teachers and students ratio. In addition, digital piano belongs to electronic products, It does not have the sound principle of the physical percussion of the traditional piano, compared to the traditional piano, there are essential differences in playing strength and vocal tone. Students who play the digital pianos often also reflect the unaccustomed to playing the traditional piano. This requires the school to provide students with a formal piano practice room for students to practice in their spare time and to ensure the students' adaptability to playing the traditional piano.

2) Instructional mode: Traditional piano teaching takes the form of one-on-one instruction, however, due to the particularity of pre-school education professional piano course, traditional piano teaching forms cannot meet the current teaching needs. At present, the pre-school education professional piano courses in universities are mainly in the form of collective teaching.

Compared with traditional one-on-one piano teaching, besides saving education investment and alleviating the shortage of teachers, the collective teaching form, the teacher does not need to repetitive work; solve students' same problems through class teaching. Students can clearly understand their playing level with other students through collective teaching [2], enhance the enthusiasm of learning in an active classroom atmosphere. The deficiency of the form of collective teaching mainly lies in the teacher's inability to take care of every student in the class, there is no way to address the different finger technology problems that each student appears in playing. The degree of practice and acceptance of each student in the piano learning process is different, long-term and unified learning progress will make some of the slower learners lose motivation. In the same way, long-term and unified learning progress can also affect students with strong learning ability, reduce the students' learning progress, thus affecting the teaching effect [3].

3) The teaching content: The pre-school education professional piano course is different from the piano major of the general music college. The piano major of the general music college is mainly to cultivate students' professional piano playing ability, but it is necessary to have the ability to play the piano, sing while playing the piano, and the impromptu accompaniment of children's songs. Only with these three capabilities at the same time, can we meet the requirements of future kindergarten work. Piano playing level is the foundation, is the piano level embodiment. Sing while playing the piano is the combination of piano and vocal music, which is the embodiment of the coordination ability of the hand mouth. The impromptu accompaniment of children's songs is the most important thing in the future work, it is the combination of theory and practice. Pre-school education students have a large number of study courses and limited class hours. How can the piano playing, sing while playing the piano, and the impromptu accompaniment of children's songs in this limited period of time, so that the students level to the future work requirements, can balance the proportion of learning in these three aspects, it is an important question that must be considered in the teaching of education professional piano course.

\section{THOUGHTS AND SUGgestions ON THE CURRENT} TEACHING Situation of Professional Piano COURSES IN PRE-SCHOOL EDUCATION

\section{A. To Create a Good Environment for Teaching and Learning}

Pre-school education professional piano course has certain particularity, which is a combination of theory and practice, students need to apply the theoretical knowledge they have learned to piano playing, with a lot of playing practice to achieve a certain level of piano playing, however, a good teaching environment is the guarantee of all this.

First of all, the professional piano course of education in university needs to improve the teaching hardware level. Current pre-school education professional piano lessons are mainly taught with digital pianos, digital piano belongs to electronic products, which is different from traditional piano, 
therefore, when choosing the digital piano brand and model, the university should choose the big brand and choose the digital piano with the technology of step by step counterweight keyboard. This can guarantee the quality and after-sale service of digital piano, and avoid delay or influence of teaching progress or teaching effect due to the quality problems of digital piano, and because the step by step counterweight keyboard is closest to the touch of traditional piano, it ensures students' quick adaptation ability from playing digital piano to playing traditional piano fingers. In addition to the digital piano, the classroom should be equipped with computers, projectors, cameras, speakers and other equipment, all of these devices help teachers teach better, use more teaching methods to improve students' enthusiasm and interest in learning, so as to improve the teaching quality of piano lessons.

Second, pre-school education professional piano courses need to control the number of students in each class. Although the use of digital piano for collective teaching can save teachers and teaching input costs, modern teaching methods still need to control the number of students. Due to the particularity of piano learning, teachers need to find out the different problems that each student has in playing, and solve these problems in a targeted way. If there are too many students in a class, the teacher will not be able to take into account every student. The learning effect of the students will be greatly reduced, and it will also have an impact on the later study.

\section{B. Diversified Teaching Forms}

Using modern teaching equipment, teachers can teach in many forms. In class, the combination of collective teaching form, group class form and traditional "one-to-one" teaching form is organically combined [4]. For example: in the primary stage of the student, by using the advantages of collective teaching, the teacher can unify teaches playing piano the sitting position and the hand type, the musical knowledge, the key and the difficult points of the music, lead the students to appreciate the music works, lead the students to sing the music, beat the rhythm and so on. It cannot only avoid the repetitive work of teachers in class, but also solve the same problems that students have in the primary stage. After the students learn to a certain stage, the level of playing will inevitably lead to a certain gap. At this time, the teacher can take the form of the combination of collective teaching and group lesson in class. Grouping different degrees of students, after the unified teaching of theoretical knowledge, the teacher arranges and exercises the repertoire according to the students' learning level, and conducts the instruction in batches, encouraging the students to help each other. On the one hand, students can make rapid progress in the students with poor reception ability, on the other hand, for the better students; it is also a review and consolidation of the learned knowledge. This can not only teach students in accordance with their aptitude, but also stimulate students' selfconfidence and competition awareness, and create a positive learning atmosphere. In the middle and later stages of learning, the piano playing level gap will widen further, teachers also learn about each student's playing habits and characteristics through a long period of teaching. At this time, it is necessary to join the "one-to-one" teaching form of traditional piano teaching. Students in this period will have different problems in learning and piano playing, teachers should solve the problems according to the students' different problems, so as to improve the quality of piano playing.

\section{Rationalization of Teaching Content}

The teaching content of pre-school education professional piano course should be closely combined with the actual work of kindergarteners to increase the practicability of the course content. In the kindergarten work, the piano skill is mainly reflected in sing children's songs while playing the piano, and the impromptu accompaniment of children's songs. Therefore, in the course content arrangement, the piano playing basic training should be the first priority, solid students' basic skills, strengthening students' playing skills, training student's good reading skills and practice habits, to improve the flexibility and independence of students' fingers as much as possible during the limited period of time. After students have mastered the basics of piano playing, they can begin to learn improvisation accompaniment, and impromptu accompaniment, especially the accompaniment of children's songs, is the key point in the pre-school education professional piano class. The school should try to increase the amount of the impromptu accompaniment class and enrich the teaching content of the impromptu accompaniment course, to train the students' ability of sightreading for numbered musical notation and rapid transposing, improve the students' speed to complete the accompaniment of children's songs. During this period, students can be encouraged to sing and play piano accompaniment to each other, enable students to experience the importance of "fluency" and "integrity" while playing the accompaniment, and exercise students' accompaniment ability. Finally, students are required to sing while playing the piano the children's songs on the basis of their accompaniment, strive to achieve the coordination between hands and mouth, not affecting each other. Through a large number of children's song to sing while playing the piano and accompaniment training, the piano skill level of the students can reach the actual needs of kindergarten work, and make full preparations for the future career of preschool teachers.

\section{Improve Teaching Assessment Methods}

Nowadays, most courses in colleges and universities take the form of "final examination" as the final examination standard for students, however, piano as a skill class has certain particularity. If piano lessons are always judged by the final exam, therefore, it is easy to cause some students' slacking psychology, usually lazy, but one or two weeks before the exam to perform surprise exercises on final exam assignments. The students may not fail in the final grade, but the technical level in the actual piano playing is not solved, invisibly, the path to learning the piano for me adds more stumbling blocks, directly leading to the level of their own piano skills cannot meet the needs of future work. There is also a kind of student, psychological quality is poorer. No matter how hard you usually do in private practice, how 
skillful the repertoire is, as long as they play the piano in public or take exams, they will be too nervous to play normally, which will directly affect their final exam results [5], over time, this state will also affect the students' enthusiasm for learning. Therefore, the teaching assessment method of piano course cannot be judged by the final examination result only, it should take into account the particularity of piano lessons and increase the diversity of teaching assessment methods, so that students' learning results can have a most real manifestation. For example, the evaluation method of students' assessment is changed from the final exam to the process assessment method; periodic assessment is carried out according to the course content, or in the way of "check homework". Reduce the proportion of final assessment score, and increase the proportion of periodic assessment or "check homework" assessment score, encourage students to play their subjective initiative in the learning process, it can not only avoid students' lazy attitude, but also exercise their psychological quality. At the same time, schools can hold different art skills competitions, teachers can also be evaluated by students' performance in the competition, which is included in the final comprehensive score of the students.

\section{CONCLUSION}

As one of the most difficult courses in pre-school education professional skills, the piano lesson has always been a problem of poor teaching effect. In recent years, through the state's attention to the pre-school education major, through the continuous efforts of pre-school education professional first-line teachers, although pre-school education students have made great strides in piano skills, we find that there is still a problem with piano teaching. Firstline teachers should always reflect on themselves, while improving their own professional level, they should also reform the teaching form and teaching methods and try to train more high-quality preschool teachers.

\section{REFERENCES}

[1] Gao Yan. The Problems and Countermeasures of Piano Teaching in Preschool Education[J]. 18 rd ed. Song of the yellow river.2016,pp:20-21.

[2] Su Yu. Exploration and Analysis on the Teaching of Piano Course in Preschool Education[J]. 11 rd ed.vol. 30. Journal of Inner Mongolia normal university. 2017, pp:158-160.

[3] Zhao Jing. Analysis and research on piano teaching of music education and pre-school education major in baoshan university[D]. Master's degree thesis of Yunnan normal university.2015-05.

[4] Liu Yang. Research on preschool education piano course teaching[J]. China's off-campus education, 2010-06,pp:76-78.

[5] Guan Cong. A case study on piano teaching of preschool education major in Higher Vocational Colleges[D]. Master's degree thesis of Hebei normal university.2016-10.

[6] Ying Shi-zhen. Piano teaching method[M]. People's music press.1990.

[7] Wang Li. On the innovation of preschool education piano teaching[J]. Home drama.2014.

[8] Li Muyi. Discussion on piano teaching of education major in preschool[J]. Education teaching forum.2012, pp136-137. 